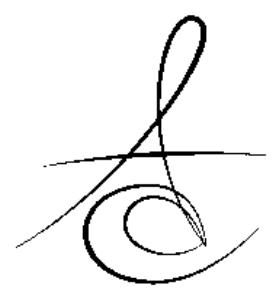

\section{ASSESSMENT OF KNOWLEDGE AND ATTITUDES TOWARD PERIODONTAL HEALTH AMONG PARENTS OF PEDIATRIC DENTISTRY PATIENTS}

PEDODONTİ HASTALARININ EBEVEYNLERİNİN PERİODONTAL SAĞLIĞA İLISŞKİN BİLGİ VE TUTUMLARININ DEĞERLENDİRİLMESİ

\author{
Dr.öğr. Üyesi Meltem KARŞIYAKA HENDEK* \\ Dr. Didem BEZÍRCI ${ }^{*}$
}

\author{
Dr.Öğr. Üyesi Merve ERKMEN ALMAZ** \\ Prof.Dr. Ebru OLGUN ${ }^{*}$
}

Makale Kodu/Article code: 4051

Makale Gönderilme tarihi: 29.04.2019

Kabul Tarihi: 08.08.2019

\section{ABSTRACT}

Aim: Family is the most important environment where children acquire knowledge, attitudes, and habits related to oral health. The aim of this study was to evaluate the knowledge and attitudes of parents toward periodontal health and diseases, and the relationship of their knowledge and attitudes with demographic data.

Materials and Methods: 500 parents, referred for the treatment of their children were included in the study. The knowledge and attitudes of the parents were assessed using a self-administered and structured questionnaire. Data were analyzed by chi-square test, with the level of significance set at $p<0.05$.

Results: $33.0 \%$ parents and $33.6 \%$ children brushed their teeth twice or more daily. $17 \%$ parents and $8.6 \%$ children used dental floss/interdental brush, and $77 \%$ parents visited a dentist only when they experienced dental complaints. Most parents incorrectly defined the meaning of dental plaque and did not know its role in the etiology of gingival diseases. $47.4 \%$ of them were aware that bleeding gums indicated the presence of periodontal disease, while only $11.8 \%$ knew that one of the main reasons of tooth loss was periodontal disease. It was also evident that the use of dental floss significantly increased with an increase in income level $(p<0.05)$, and the knowledge and attitude of the parents regarding periodontal health significantly increased with the educational level $(p<0.05)$.

Conclusion: The knowledge and attitude of the parents regarding periodontal health were poor. Thus, an improvement in the knowledge and awareness among the parents can prevent or reduce the severity of possible periodontal problems in their children.

Key words: Attitude; Child; Knowledge; Parent; Periodontal health

\section{öz}

Amaç: Aile, çocukların ağız sağlığı ile ilgili alışkanlık, bilgi ve tutumlarında etkisi olan en önemli ortamdır. Bu çalışmanın amacı, ebeveynlerin periodontal sağlık ve hastalığa yönelik bilgi ve tutumlarını değerlendirmek ve bilgi ve tutumlarının demografik verilerle ilişkisini araştırmaktı.

Gereç ve Yöntem: Çocuklarının tedavisi için başvuran 500 ebeveyn çalışmaya dahil edilmiştir. Ebeveynlerin bilgi ve tutumları, yapılandırılmış bir anket kullanılarak değerlendirilmiştir. Veriler ki-kare testi ile analiz edilmiş, anlamlılık düzeyi $p<0.05$ olarak belirlenmiştir.

Bulgular: Ebeveynlerin \%33.0'ı ve çocukların \% 33.6'sı dişlerini günde iki veya daha fazla fırçalamaktadır. Ebeveynlerin \%17'si ve çocukların \%8.6'sı diş ipi/arayüz fırçası kullandığını ve \%77'si dental şikayetleri bulunması durumunda diş hekimini ziyaret ettiğini belirtmiştir. Ebeveynlerin çoğunluğu dental plağı yanlış tanımlamış ve diş eti hastalıklarının etiyoloji sindeki rolüne doğru cevap vermemiştir. \%47.4'ü dişeti kanamasının periodontal hastalığı işaret ettiğini ve \%11.8'i diş kaybının ana nedenlerinden birinin de periodontal hastalık olduğunu bildiğini belirtmiştir. Ayrıca diş ipi kullanımının gelir düzeyi arttıkça anlamlı şekilde arttığı $(p<0.05)$ ve ebeveynlerin periodontal sağlık konusundaki bilgi ve tutumlarının eğitim düzeyi ile anlamlı olarak arttığı da gözlenmiştir $(p<0.05)$.

Sonuç: Ebeveynlerin periodontal sağlık konusundaki bilgi ve tutumu zayıf bulunmuştur. Bu nedenle, ebeveynlerin bilgi ve farkındalıklarında bir gelişme, çocuklarında olası birçok periodontal sorunun ciddiyetini önleyebilir veya azaltabilir.

Anahtar kelimeler: Tutum; Çocuk; Bilgi; Ebeveyn; Periodontal sağlık

*Department of Periodontology, Faculty of Dentistry, Kirikkale University, Kirikkale, Turkey

${ }^{* *}$ Department of Pediatric Dentistry, Faculty of Dentistry, Kirikkale University, Kirikkale, Turkey 
Atatürk Üniv. Diş Hek. Fak. Derg.

J Dent Fac Atatürk Uni

Cilt:29, Sayı:4, Yıl: 2019, Sayfa, 604-610
KARŞIYAKA HENDEK, ERKMEN ALMAZ, BEZIRCI OLGUN

\section{INTRODUCTION}

Periodontal diseases are one of the most common problems observed in individuals of all races and socioeconomic status. ${ }^{1}$ Although public opinion indicates that these diseases mostly affect adults, studies have shown that children and adolescents are also extensively affected by periodontal diseases. ${ }^{2,3}$ Periodontal diseases usually occur due to dental plaque and may cause a premature loss of deciduous or permanent teeth, by affecting the periodontal tissues such as cementum, periodontal ligament, and alveolar bone. Adequate oral hygiene motivation and regular prophylaxis, as dictated by an early and accurate diagnosis, can prevent or reduce the severity of periodontal diseases. ${ }^{4-6}$ Furthermore, an improvement in the level of periodontal health awareness and knowledge has been known to favorably influence the practices and behaviors related to periodontal health. Likewise, improving the periodontal health awareness of parents would result into an improved probability of early diagnosis, thereby helping in the prevention and control of periodontal diseases in them and their children. Briefly, the oral health practices of parents reflect their understanding of the importance of periodontal health, affecting the oral health maintenance in them and their children.

However, in the literature, scarce information is available on the knowledge and awareness of the parents of pediatric dentistry patients with regards to periodontal health and there is no study evaluating the relationship between parents' knowledge and attitudes with their children's oral health behaviors. Therefore, the aim of this study was to evaluate the knowledge, attitudes, and practices of the parents regarding periodontal health and diseases, and to investigate the relationship of their knowledge and attitudes with the demographic data and their children's oral health behaviors. In this study, because periodontal diseases are generally ignored by individuals, it was hypothesized that the knowledge and attitudes of the parents regarding periodontal health might be poor.

\section{SUBJECTS AND METHODS \\ Study population}

The study was conducted among the parents seeking dental treatment for their children in the Department of Pediatric Dentistry at the Faculty of
Dentistry, Kirikkale University between June 2017 and November 2017. The study was approved by the Ethics Committee of Kirikkale University, Kirikkale, Turkey (February 28, 2017-06/02). Before participation, all participants were informed about the study goals and procedures and all participants gave written informed consent in accordance with the Declaration of Helsinki.

\section{Questionnaire}

A self-administered, structured questionnaire was completed by the parents during a six-month period. The questionnaire included items related to personal and sociodemographic data, periodontal awareness and knowledge, and self-reported behaviors to dental attendance. The questions in the first section dealt with personal and sociodemographic data. The knowledge, attitudes, and practice regarding periodontal health and disease were assessed through a series of questions in the second section of the questionnaire. Subjects were asked to respond according to the response format provided at the end of each question.

The questionnaire data were analyzed by means of computerized SPSS statistical package (SPSS Inc., Chicago, IL, USA). Frequency distributions were used along with chi-square tests at $p<0.05$.

\section{RESULTS}

\section{Demographic data}

Out of a total of 516 parents invited to participate in this study, 500 parents (females $n=298$; males $n=202$, with a mean age of $36.8 \pm 6.4$ years) returned the completed questionnaires, accounting for a response rate of $96.9 \%$. The demographic data are shown in Table 1.

\section{Knowledge and attitudes about periodontal health among the parents}

Around $33.0 \%$ parents and $33.6 \%$ children brushed their teeth twice or more daily, whereas, around $17.0 \%$ parents and $8.6 \%$ children used dental floss/interdental brushes. $39.8 \%$ parents brushed for duration of $2 \mathrm{~min}$, and $39.6 \%$ of them changed their brushes every 3 months.

$77.0 \%$ of the parents visited a dentist only when they experienced dental pain, $11.4 \%$ of them believed it as a necessity to visit a dentist at least every six months, and $11.6 \%$ of them visited a dentist only once or twice a year. Similarly, $71.0 \%$ of the

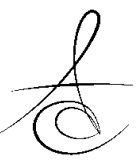


parents went to a dentist for their children only when they had dental complaints. Moreover, $61.2 \%$ of the parents and only $9.8 \%$ of the children received prior periodontal treatment. Furthermore, a minority (8.8\%) of the parents had knowledge or ability to define dental plaque as a soft deposit on the tooth surfaces, and around $33.4 \%$ of them had knowledge of the cause of periodontal diseases to be dental plaque. Additionally, $47.4 \%$ of the parents were aware that bleeding gums indicated the presence of periodontal disease, and $11.8 \%$ of the parents were aware that one of the main reasons of tooth loss was periodontal disease. Furthermore, $75.4 \%$ of the parents answered that gum diseases can be prevented by brushing and flossing (Table 2).

Table 1. Socio-demographic characteristics of parents

\begin{tabular}{lcc}
\hline Gender & Frequency (n) & Percentage (\%) \\
Female & 298 & 59.4 \\
Male & 202 & 40.6 \\
Area & & \\
Province & 494 & 98.8 \\
Rural & 6 & 1.2 \\
Education & & \\
Never been to school & 0 & 0 \\
Primary school & 134 & 26.8 \\
Secondary school & 203 & 40.6 \\
University & 163 & 32.6 \\
Income & & \\
<2000 TL & 172 & 34.4 \\
2001-3000 TL & 150 & 30.0 \\
3001-5000 TL & 128 & 25.6 \\
5001-8000 TL & 37 & 7.4 \\
>8001 TL & 13 & 2.6 \\
\hline
\end{tabular}

\section{Comparison of the parents' knowledge and attitudes about periodontal health according to demographic data}

The comparison of parents' knowledge and attitudes toward periodontal health according to their educational levels is shown in Table 3. There was a significant difference in the responses to "How often do you go to a dentist?," "Do you use dental floss?" "What is plaque?," "What can plaque cause?," "What do 'bleeding gums' indicate?," and "How can you prevent gum diseases?," between different educational levels $(p<0.05)$.

The comparison of parents' use of dental floss with their income levels is shown in Table 3. The percentage use of dental floss significantly increased with an increase in the income level, from $10.5 \%$ at $<2000 \mathrm{TL}, 16.7 \%$ at $2001-3000 \mathrm{TL}, 19.7 \%$ at $3001-$ $5000 \mathrm{TL}, 32.4 \%$ at $5001-8000 \mathrm{TL}$, to $38.5 \%$ at
$>8001 T L(p=0.003)$.

There was also a statistically significant relationship between the parents and their children with regard to the frequency of dental visits, brushing, and flossing, as shown in Table 4.

Table 2. Knowledge and attitudes toward periodontal health among parents

\begin{tabular}{|c|c|c|c|c|}
\hline & $\begin{array}{l}\text { Frequency } \\
\text { (n) }\end{array}$ & $\begin{array}{l}\text { Percentage } \\
(\%)\end{array}$ & $\chi^{2}$ & $\mathbf{P}$ \\
\hline \multicolumn{5}{|c|}{ Frequency of dental visit (for parents) } \\
\hline Every one to two years & 58 & 11.6 & 429.028 & .000 \\
\hline Every six month & 57 & 11.4 & & \\
\hline $\begin{array}{l}\text { Whenever you get a dental } \\
\text { problem }\end{array}$ & 385 & 77.0 & & \\
\hline \multicolumn{5}{|c|}{ Frequency of dental visit (for children) } \\
\hline Every one to two years & 47 & 9.4 & 873.214 & .000 \\
\hline Every six month & 98 & 19.6 & & \\
\hline $\begin{array}{l}\text { Whenever you get a dental } \\
\text { problem }\end{array}$ & 355 & 71.0 & & \\
\hline \multicolumn{5}{|c|}{$\begin{array}{l}\text { Getting of periodontal treatment before } \\
\text { (for parents) }\end{array}$} \\
\hline Yes & 306 & 61.2 & 24.691 & .000 \\
\hline No & 194 & 38.8 & & \\
\hline \multicolumn{5}{|c|}{$\begin{array}{l}\text { Getting of periodontal treatment before? } \\
\text { (for children) }\end{array}$} \\
\hline Yes & 49 & 9.8 & 321.285 & .000 \\
\hline No & 451 & 90.2 & & \\
\hline \multicolumn{5}{|l|}{$\begin{array}{l}\text { Frequency of brushing (for } \\
\text { parents) }\end{array}$} \\
\hline Occasionally & 107 & 21.4 & & \\
\hline Once daily & 228 & 45.6 & 187.120 & .000 \\
\hline Two or more times daily & 165 & 33.0 & & \\
\hline \multicolumn{5}{|c|}{ Frequency of brushing (for children) } \\
\hline Occasionally & 120 & 24.0 & & \\
\hline Once daily & 212 & 42.4 & 559.177 & .000 \\
\hline Two or more times daily & 168 & 33.6 & & \\
\hline \multicolumn{5}{|l|}{ Use of flossing (for parents) } \\
\hline Yes & 85 & 17.0 & 217.800 & .000 \\
\hline No & 415 & 83.0 & & \\
\hline \multicolumn{5}{|l|}{ Use of flossing (for children) } \\
\hline Yes & 43 & 8.6 & 341.822 & .000 \\
\hline No & 457 & 91.4 & & \\
\hline \multicolumn{5}{|l|}{ Brushing time } \\
\hline Less than 1 minute & 232 & 46.4 & & \\
\hline Brushing time 2 minutes & 199 & 39.8 & 89.116 & .000 \\
\hline More than 2 minutes & 69 & 13.8 & & \\
\hline \multicolumn{5}{|l|}{ Frequency of brush change } \\
\hline Monthly & 88 & 17.6 & & \\
\hline 3 monthly & 198 & 39.6 & 107.168 & .000 \\
\hline 6 monthly & 162 & 32.4 & & \\
\hline Yearly & 52 & 10.4 & & \\
\hline \multicolumn{5}{|l|}{ What is plaque? } \\
\hline Soft deposits on teeth & 44 & 8.8 & & \\
\hline Hard deposits on teeth & 204 & 40.8 & 290.140 & .000 \\
\hline Staining on teeth & 82 & 16.4 & & \\
\hline Do not know & 170 & 34.0 & & \\
\hline \multicolumn{5}{|l|}{ What can plaque cause? } \\
\hline Gum disease & 167 & 33.4 & & \\
\hline Discolouration of teeth & 118 & 23.6 & 558.624 & .000 \\
\hline Malformation of teeth & 29 & 5.8 & & \\
\hline Do not know & 186 & 37.2 & & \\
\hline \multicolumn{5}{|l|}{ What do 'bleeding gums' indicate? } \\
\hline Inflamed gums & 237 & 47.4 & & \\
\hline Healthy gums & 4 & .8 & 404.340 & .000 \\
\hline Gum recession & 162 & 32.4 & & \\
\hline Do not know & 97 & 19.4 & & \\
\hline \multicolumn{5}{|l|}{ What are the reasons of tooth loss? } \\
\hline Periodontal disease & 59 & 11.8 & & \\
\hline Tooth decay & 200 & 40.0 & 943.744 & .000 \\
\hline Aging & 5 & 1.0 & & \\
\hline Others & 14 & 2.8 & & \\
\hline All of them & 222 & 44.4 & & \\
\hline \multicolumn{5}{|c|}{ How can you prevent gum diseases? } \\
\hline By brushing and flossing & 377 & 75.4 & & \\
\hline By using soft diet & 5 & 1.0 & 1294.495 & .000 \\
\hline By taking Vit. C & 20 & 4.0 & & \\
\hline Do not know & 98 & 19.6 & & \\
\hline
\end{tabular}


Atatürk Üniv. Diş Hek. Fak. Derg.

J Dent Fac Atatürk Uni

Cilt:29, Sayı:4, Yıl: 2019, Sayfa, 604-610

KARŞIYAKA HENDEK,

ERKMEN ALMAZ, BEZIRCI, OLGUN

Table 3. Knowledge and attitudes toward periodontal health among parents according to education and income level $\mathrm{n}(\%)$

\begin{tabular}{|c|c|c|c|c|c|c|c|c|c|}
\hline & & \multicolumn{5}{|c|}{ Education Level } & \multirow[b]{2}{*}{ Total } & \multirow[b]{2}{*}{$\boldsymbol{x}^{2}$} & \multirow[b]{2}{*}{$\mathbf{P}$} \\
\hline & & $\begin{array}{l}\text { Primary } \\
\text { school }\end{array}$ & \multirow{2}{*}{\multicolumn{2}{|c|}{$\begin{array}{l}\begin{array}{l}\text { Secondary } \\
\text { school }\end{array} \\
21(36.8)\end{array}$}} & \multicolumn{2}{|c|}{ University } & & & \\
\hline \multirow{3}{*}{$\begin{array}{l}\text { Frequency of } \\
\text { dental visit } \\
\text { (for parents) }\end{array}$} & \multirow{3}{*}{$\begin{array}{l}\text { Every six month } \\
\text { Every one to two } \\
\text { years } \\
\text { Whenever you } \\
\text { get a dental } \\
\text { problem }\end{array}$} & $15(26.4)$ & & & \multicolumn{2}{|c|}{$21(36.8)$} & 57 & & \\
\hline & & $16(27.6)$ & \multicolumn{2}{|c|}{$18(31.0)$} & \multicolumn{2}{|c|}{$24(41.4)$} & 58 & & \\
\hline & & $103(26.8)$ & \multicolumn{2}{|c|}{$164(42.6)$} & \multicolumn{2}{|c|}{$118(30.6)$} & 385 & 21.196 & 0.007 \\
\hline \multirow{2}{*}{$\begin{array}{l}\text { Use of } \\
\text { flossing } \\
\text { (for parents) }\end{array}$} & Yes & $14(16.5)$ & \multirow{2}{*}{\multicolumn{2}{|c|}{$\begin{array}{l}23(27.1) \\
180(43.4)\end{array}$}} & \multirow{2}{*}{\multicolumn{2}{|c|}{$\begin{array}{l}48(56.4) \\
115(27.7) \\
\end{array}$}} & 85 & & \\
\hline & No & $120(28.9)$ & & & & & 415 & 28.850 & 0.000 \\
\hline \multirow{3}{*}{$\begin{array}{l}\text { What is } \\
\text { Plaque? }\end{array}$} & $\begin{array}{l}\text { Soft deposits on } \\
\text { teeth }\end{array}$ & $8(18.2)$ & \multicolumn{2}{|c|}{$16(36.4)$} & \multicolumn{2}{|c|}{$20(45.4)$} & 44 & & \\
\hline & Hard deposits on & $35(17.2)$ & \multicolumn{2}{|c|}{$72(35.3)$} & \multicolumn{2}{|c|}{$97(47.5)$} & 204 & & \\
\hline & $\begin{array}{l}\text { Staining on teeth } \\
\text { Do not know }\end{array}$ & $\begin{array}{l}18(22.0) \\
73(42.9)\end{array}$ & \multicolumn{2}{|c|}{$\begin{array}{l}39(47.6) \\
76(44.7)\end{array}$} & \multicolumn{2}{|c|}{$\begin{array}{l}25(30.4) \\
21(12.4)\end{array}$} & $\begin{array}{l}82 \\
170\end{array}$ & 72.708 & 0.000 \\
\hline \multirow{4}{*}{$\begin{array}{l}\text { What can } \\
\text { plaque cause? }\end{array}$} & Gum disease & $25(15.0)$ & \multicolumn{2}{|c|}{$56(33.5)$} & \multicolumn{2}{|c|}{$86(51.5)$} & 167 & & \\
\hline & $\begin{array}{l}\text { Discolouration } \\
\text { of teeth }\end{array}$ & $21(17.8)$ & \multicolumn{2}{|c|}{$58(49.1)$} & \multicolumn{2}{|c|}{$39(33.1)$} & 118 & & \\
\hline & $\begin{array}{l}\text { Malformation of } \\
\text { teeth }\end{array}$ & $10(34.5)$ & \multicolumn{2}{|c|}{$9(31.0)$} & \multicolumn{2}{|c|}{$10(34.5)$} & 29 & 83.663 & 0.000 \\
\hline & Do not know & $78(42.0)$ & \multicolumn{2}{|c|}{$80(43.0)$} & \multicolumn{2}{|c|}{$28(15.0)$} & 186 & & \\
\hline $\begin{array}{l}\text { What do } \\
\text { 'bleeding }\end{array}$ & $\begin{array}{l}\text { Inflamed gums } \\
\text { Healthy gums } \\
\text { Gum recession }\end{array}$ & $\begin{array}{l}60(25.3) \\
1(25.0) \\
38(23.5)\end{array}$ & & $\begin{array}{l}(39.2) \\
(5.0) \\
(40.1)\end{array}$ & & $(36.4)$ & $\begin{array}{l}237 \\
4 \\
162\end{array}$ & & \\
\hline $\begin{array}{l}\text { gums' } \\
\text { indicate? }\end{array}$ & Do not know & $35(36.1)$ & & $(43.3)$ & & $(20.6)$ & 97 & 39.275 & 0.001 \\
\hline & $\begin{array}{l}\text { By brushing and } \\
\text { flossing }\end{array}$ & $103(27.3)$ & & $(37.4)$ & & $(35.3)$ & 377 & & \\
\hline $\begin{array}{l}\text { How can you } \\
\text { prevent gum }\end{array}$ & $\begin{array}{l}\text { By using soft } \\
\text { diet }\end{array}$ & $0(0)$ & 0 & & & $.00 .0)$ & 5 & & 0.000 \\
\hline diseases? & By taking Xit, $\mathrm{C}$ & $6(30.0)$ & & $5.0)$ & & $5.0)$ & 20 & 52.376 & \\
\hline & Do not know & $25(25.5)$ & & (54.1) & & $(20.4)$ & 98 & & \\
\hline & & Income Lev & vel & & & & & & \\
\hline & & $\begin{array}{l}<2000 \\
\text { TL }\end{array}$ & $\begin{array}{l}2001- \\
3000 \\
\text { TL }\end{array}$ & $\begin{array}{l}3001- \\
5000 \mathrm{TL}\end{array}$ & $\begin{array}{l}5001- \\
8000 \\
\text { TL }\end{array}$ & $\begin{array}{l}>8001 \\
\mathrm{TL}\end{array}$ & & & \\
\hline & Yes & $\begin{array}{c}18 \\
(10.5)\end{array}$ & $\begin{array}{l}25 \\
(16.7)\end{array}$ & $25(19.7)$ & $\begin{array}{l}12 \\
(32.4)\end{array}$ & $\begin{array}{l}5 \\
(38.5)\end{array}$ & 85 & & \\
\hline $\begin{array}{l}\text { Use of flossing } \\
\text { (for parents) }\end{array}$ & No & $\begin{array}{c}154 \\
(89.5)\end{array}$ & $\begin{array}{l}125 \\
(83.3)\end{array}$ & $\begin{array}{l}103 \\
(80.3)\end{array}$ & $\begin{array}{l}25 \\
(67.6)\end{array}$ & $\begin{array}{l}8 \\
(61.5)\end{array}$ & 415 & 15.870 & 0.003 \\
\hline
\end{tabular}

Table 4. Relationship between frequency of dental visit, brushing and use of flossing between parents and children $\mathrm{n}(\%)$

\begin{tabular}{|c|c|c|c|c|c|c|c|}
\hline \multirow{5}{*}{$\begin{array}{c}\text { Frequency of } \\
\text { dental visit } \\
\text { (for parents) }\end{array}$} & \multirow{5}{*}{$\begin{array}{c}\text { Every six month } \\
\text { Every one to two } \\
\text { years } \\
\text { Whenever you get } \\
\text { a dental problem }\end{array}$} & \multicolumn{3}{|c|}{ Frequency of dental visit (for children) } & \multirow[b]{2}{*}{ Total } & \multirow[b]{2}{*}{$x^{2}$} & \multirow[b]{2}{*}{$\mathbf{P}$} \\
\hline & & $\begin{array}{l}\text { Every six } \\
\text { month }\end{array}$ & $\begin{array}{c}\text { Every one to } \\
\text { two years }\end{array}$ & $\begin{array}{c}\text { Whenever you get a } \\
\text { dental problem }\end{array}$ & & & \\
\hline & & $38(66.7)$ & $4(7.0)$ & $15(26.3)$ & 57 & \multirow{3}{*}{140.031} & \multirow{3}{*}{0.000} \\
\hline & & $16(27.6)$ & $16(27.6)$ & $26(44.8)$ & 58 & & \\
\hline & & $44(11.4)$ & $26(6.8)$ & $315(81.8)$ & 385 & & \\
\hline \multicolumn{8}{|c|}{ Frequency of brushing (for children) } \\
\hline \multirow{5}{*}{$\begin{array}{c}\text { Frequency of } \\
\text { brushing (for } \\
\text { parents) }\end{array}$} & & Occasionally & Once daily & $\begin{array}{c}\text { Two or more times } \\
\text { daily }\end{array}$ & Total & $\boldsymbol{x}^{2}$ & $\mathbf{P}$ \\
\hline & Occasionally & $88(82.2)$ & $15(14.1)$ & $4(3.7)$ & 107 & & \\
\hline & Once daily & $180(78.9)$ & $42(18.4)$ & $6(2.7)$ & 228 & & \\
\hline & $\begin{array}{c}\text { Two or more times } \\
\text { daily }\end{array}$ & $59(35.8)$ & $97(58.8)$ & $9(5.4)$ & 165 & 158.218 & 0.000 \\
\hline & & \multicolumn{3}{|c|}{ Use of flossing (for children) } & & & \\
\hline & & \multirow{2}{*}{\multicolumn{2}{|c|}{$\begin{array}{c}\text { Yes } \\
18(21.2) \\
25(6.0) \\
\end{array}$}} & $\begin{array}{c}\text { No } \\
67(78.8)\end{array}$ & $\begin{array}{c}\text { Total } \\
85\end{array}$ & $\boldsymbol{x}^{2}$ & $\mathbf{P}$ \\
\hline $\begin{array}{l}\text { Use of flossing } \\
\text { (for parents) }\end{array}$ & $\begin{array}{l}\text { Yes } \\
\text { No }\end{array}$ & & & $\begin{array}{c}67(78.8) \\
390(94.0)\end{array}$ & $\begin{array}{c}85 \\
415\end{array}$ & 20,522 & 0.000 \\
\hline
\end{tabular}


Atatürk Üniv. Diş Hek. Fak. Derg.

J Dent Fac Atatürk Uni

Cilt:29, Sayı:4, Yıl: 2019, Sayfa, 604-610
KARŞIYAKA HENDEK, ERKMEN ALMAZ, BEZIRCI OLGUN

\section{DISCUSSION}

Periodontal disease progression usually goes unnoticed by most population, and people probably recognize it only when it reaches an advanced stage. The responsible periodontal health behaviors, such as brushing, flossing, and regular dental visits, play an important role in maintaining periodontal health. The quality of periodontal health depends upon the level of available information, knowledge, awareness, practice, and nutrition. Family is the first and most important factor for children to acquire knowledge, attitudes, and habits related to oral health. ${ }^{7}$ The oral health behaviors of children are not only totally explained by the knowledge and attitudes, but are also influenced by the educational level, awareness, and practices of their parents. In the present study, we evaluated the knowledge and attitudes toward periodontal health, among parents of pediatric dentistry patients. Unfortunately, poor knowledge and attitudes of the parents regarding periodontal health were found.

Gingival bleeding is the first symptom of gingival diseases, and since it can be easily selfdetected, it is the most reliable indicator of the condition. ${ }^{8}$ Therefore, to prevent the development of periodontal problems, the public needs to be educated enough to correlate gingival bleeding with the occurrence of gingival diseases. ${ }^{9}$ This can be achieved by improving the knowledge and awareness about periodontal conditions by dental health education. ${ }^{10}$ In our study, only $47.4 \%$ of the parents reported that bleeding indicates the presence of inflamed gums. Likewise, according to Brady, $73.0 \%$ of the patients with periodontal disease did not know that they had the disease. ${ }^{11}$ Moreover, Taani reported that $60.8 \%$ of Jordanian adults knew that gingival bleeding was indicative of inflamed gums. ${ }^{12}$

Early diagnosis is crucial for the treatment of periodontal diseases. When these diseases are not noticed or treated, they result in tooth loss. Periodontal disease is one of the most common causes of tooth loss due to being unnoticed, since it usually does not involve any pain. In the present study, $11.8 \%$ of the parents were aware that one of the main reasons of tooth loss was periodontal disease. Moreover, $44.4 \%$ of the parents answered the question, "What are the reasons of tooth loss?" as "all of them (periodontal disease, tooth decay, and aging)."
Furthermore, the results of this study emphasized the limited knowledge of the parents regarding the definition and role of dental plaque in periodontal diseases. Only $8.8 \%$ of the parents defined plaque as soft deposits on teeth, and only $33.4 \%$ of the parents had knowledge of the cause of gum diseases to be dental plaque. Poor knowledge of the gum diseases thus seems to be prevalent among the parents and needs to be corrected by oral health education.

Although, chronic inflammatory periodontal diseases are universal, the healthcare professionals know that prevention, management, and control of these diseases is possible. ${ }^{13}$ Self-oral care practice of the individuals is a preventive measure to maintain good oral and periodontal health. Likewise, better periodontal health is shown to be correlated with brushing and flossing. ${ }^{14}$ In the present study, 33.0\% of the parents brushed their teeth twice or more daily, and $17 \%$ of them performed dental flossing. Around $39.8 \%$ of them brushed their teeth for 2 minutes, and $39.6 \%$ of them changed their brushes once in 3 months. Surprisingly, three quarters of the parents knew that gum diseases can be prevented by brushing and flossing, in contrast with the findings of the studies conducted by Nyandindi et al. ${ }^{15}$, Sekhar et al. ${ }^{16}$, and Khan et $a / .{ }^{17}$. In these studies, only about $50 \%$ of the school teachers believed that regular brushing could prevent gum diseases.

In our study, $11.6 \%$ of the population visited a dentist only once or twice a year. Similarly, Jiang et al. reported that only $18.9 \%$ of the study population visited a dentist at least once per year. ${ }^{18}$

In the present study, there was a significant difference in the responses to the questions, "How often do you go to a dentist?," "Do you use dental floss?," "What is plaque?," "What can plaque cause?," "What do 'bleeding gums' indicate?," and "How can you prevent gum diseases?," between different educational levels. Higher the educational level, more was the knowledge, attitude, and practice. The importance of education for oral health is thus emphasized in this study. Likewise, in the study of Khanal et al., the educational status was found to have a significant effect on the knowledge regarding oral hygiene. ${ }^{19}$

In this study, the frequency of tooth brushing was higher in females than in males. Furthermore,

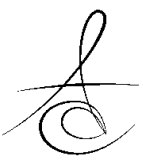


dental flossing was influenced by the income levels of the individuals. Thus, when the level of income increased, the use of dental floss also increased. This could be attributable to the high cost of the flossing instruments. Similarly, Kumar et al. reported that socioeconomic status of a family is important in predicting oral hygiene, because children living in families with lower socioeconomic status had worse oral hygiene in their study. ${ }^{20}$

In the study of Okada et al., a significant correlation was found in the oral health behaviors of parents and their children. ${ }^{21}$ Similarly, in the present study, there was a statistically significant relation between the parents and their children with respect to the frequency of dental visits, brushing, and flossing. Our study results thus justify the contribution of a family on the oral health behaviors of the children. Parents are the promoters for their children to maintain oral health. ${ }^{22,23}$ Children are affected by the attitudes, beliefs, and behaviors of their family and can have enough ability of maintaining oral hygiene, provided there is a successful model for them. ${ }^{24}$ Okada et al. reported that if parents received oral health education, children were found to be more successful in improving their gingival health. ${ }^{22}$ Likewise, Bandura ${ }^{25}$ pointed out that children perform favorable behaviors when they receive positive feedback from peers, parents, or teachers.

A lack of dental and periodontal examination of the children can be considered as a limitation of this study.

\section{CONCLUSION}

In conclusion, the knowledge and attitudes of the parents toward their oral and periodontal health is one of the most important factors determining the oral hygiene and health of their children. Educating parents might influence their children's behavior and knowledge about oral health, which can be a promising approach toward planning interventions to prevent oral diseases. It should not be forgotten that parents can serve as models for their children. Thus, long-term awareness programs are needed to improve the knowledge, attitudes, and behaviors among parents toward periodontal health and diseases.
Meltem Karsiyaka Hendek: ORCID ID: 0000-0003-15184159

Merve Erkmen Almaz: ORCID ID: 0000-0001-6766-2023

Didem Bezirci: ORCID ID: 0000-0001-9378-0453

Ebru Olgun: ORCID ID: 0000-0001-7298-8589

\section{REFERENCES}

1. Albandar JM, Rams TE. Global epidemiology of periodontal diseases: an overview. Periodontol 2000 2002;29:7-10.

2. Albandar JM, Tinoco EMB. Global epidemiology of periodontal diseases in children and young persons. Periodontol 2000 2002;29:153-76.

3. Jenkins WM, Papapanou PN. Epidemiology of periodontal disease in children and adolescents. Periodontol 2000 2001;26:16-32.

4. Chapple IL, Van der Weijden F, Doerfer C, Herrera D, Shapira L, Polak D, et al. Primary prevention of periodontitis: managing gingivitis. J Clin Periodontol 2015;42 Suppl 16:71-6.

5. Needleman I, Nibali L, Di Iorio A. Professional mechanical plaque removal for prevention of periodontal diseases in adults--systematic review update. J Clin Periodontol 2015;42 Suppl 16:1235.

6. Kara MC, Zihni M. Erzurum bolgesindeki hastalarin agiz ve periodontal saglik konusundakì bìlgì düzeylerí. Atatürk Üniv Diş Hek Fak Derg 2004;14:1-8.

7. Beljan M, Puharić Z, Žulec M, Borić D, Neumuller KR. Parent's and children's behavior and knowledge about oral health. Acta Med Croatica 2016;70:165-71.

8. Walsh MM. Effects of school based dental health education on knowledge, attitudes and behavior of adolescents in San Francisco. Community Dent Oral Epidemiol 1985;13:143-7.

9. Murtomaa H, Meurman J, Rytomaa I, Turtola L. Periodontal status in university students. J Clin Periodontol 1987; 14:462-5.

10. Murtomaa $H$, Ahlberg J, Mestsaniitty $M$. Periodontal awareness among adult Finns in 1972 and 1990. Acta Odontol Scand 1997;55:4952.

11. Brady W. Periodontal disease awareness. J Am Dent Assoc 1984;109:706-10.

12. Taani DQ. Periodontal awareness and knowledge, and pattern of dental attendance among adults in Jordan. Int Dent J 2002;52:948. 
13. Croxson LJ. Periodontal awareness: The key to periodontal health. Int Dent J 1993;43:167-77.

14. Lang WP, Ronis DL, Farghaly MM. Preventive behaviors as correlates of periodontal health status. J Public Health Dent 1995;55:10-7.

15. Nyandindi U, Palin-Palokas T, Milen A, Robison V, KombeN, Mwakasagude S. Participation, willingness and abilities of school teacher in oral health education in Tanzania. Community Dent Health 1994;11:101-4.

16. Vidya Sekhar, Sivsankar $P$, Easwaran M.A, Subitha L, Bharath N, Rajeswary $K$, et al. Knowledge, attitude and practice of school teachers towards oral health in pondicherry. J Clin Diagn Res 2014;8:12-5.

17. Khan N, Al-Shaafi M, Al-Garawi Z. Dental caries, fluorosis and knowledge of school teachers of Riyadh, Saudi Arabia. Pakistan Oral Dent J 2000;20:52-62.

18. Jiang $H$, Tai $B$, Du M. A survey on dental knowledge and behavior of mothers and teachers of school children. Hua Xi Kou Qiang Yi Xue Za Zhi 2002;20:219-20, 222.

19. Khanal K, Shrestha D, Ghimire N, Younjan R, Sanjel S. Assessment of knowledge regarding oral hygiene among parents of pre-school children attending pediatric out patient department in dhulikhel hospital. Kathmandu Univ Med J 2015;13:38-43.

20. Kumar S, Tadakamadla J, Zimmer-Gembeck M, Kroon J, Lalloo R, Johnson NW. The effect of parenting practices on the severity of gingival bleeding in children. J Periodontol 2017;88:74451.

21. Okada M, Kawamura M, Hayashi Y, Takase N, Kozai K. Simultaneous interrelationship between the oral health behavior and oral health status of mothers and their children. J Oral Sci 2008;50:447-52.

22. Okada M, Kawamura M, Kaihara Y, Matsuzaki Y, Kuwahara $S$, Ishidori $H$, et al. Influence of parents' oral health behaviour on oral health status of their school children: an exploratory study employing a causal modelling technique. Int J Paediatr Dent 2002;12:101-8.
23. Pakpour AH, Hidarnia A, Hajizadeh E, Kumar $S$, Fridlund B. Why Iranian adolescents do not brush their teeth: a qualitative study. Int J Dent Hyg 2012;10:86-90.

24. Saied-Moallemi Z, Virtanen JI, Ghofranipour F, Murtomaa $H$. Influence of mothers' oral health knowledge and attitudes on their children's dental health. Eur Arch Paediatr Dent 2008;9:7983.

25. Bandura A. Social cognitive theory of moral thought and action. In:Kurtines WM, Gewirtz JL, editors. Handbook of moral behavior and development. Hillsdale, New Jersey: Lawrence Erlbaum Associates Publishing, 1991, p.45-103.

\author{
Yazışma Adresi \\ Meltem KARSIYAKA HENDEK \\ Kirikkale University \\ Faculty of Dentistry \\ Department of Periodontology \\ Kirikkale/TURKEY \\ Tel: +90 3182244927 \\ Fax: +90 3182250685 \\ e-mail: mltmkrsyk@yahoo.com
}

